\title{
Sustainable Biofuels in the Global South
}

\author{
Hunsberger, Carol; Ponte, Stefano
}

Document Version

Accepted author manuscript

\section{Published in:}

Geoforum

DOI:

10.1016/j.geoforum.2014.02.005

Publication date:

2014

\section{License \\ CC BY-NC-ND}

Citation for published version (APA):

Hunsberger, C., \& Ponte, S. (2014). Sustainable Biofuels in the Global South. Geoforum, 54, 243-247. https://doi.org/10.1016/j.geoforum.2014.02.005

Link to publication in CBS Research Portal

\section{General rights}

Copyright and moral rights for the publications made accessible in the public portal are retained by the authors and/or other copyright owners and it is a condition of accessing publications that users recognise and abide by the legal requirements associated with these rights.

Take down policy

If you believe that this document breaches copyright please contact us (research.lib@cbs.dk) providing details, and we will remove access to the work immediately and investigate your claim. 


\section{Sustainable Biofuels in the Global South Carol Hunsberger and Stefano Ponte}

Journal article (Post print version)

CITE: Sustainable Biofuels in the Global South. / Hunsberger, Carol; Ponte, Stefano. In: Geoforum, Vol. 54, 07.2014, p. 243-247.

DOI: 10.1016/j.geoforum.2014.02.005

Uploaded to Research@CBS: May 2017

(C) 2016. This manuscript version is made available under the CC-BY-NC-ND 4.0 license http://creativecommons.org/licenses/by-nc-nd/4.0/ 


\title{
'Sustainable' biofuels in the global South
}

\author{
Carol Hunsberger ${ }^{1}$ and Stefano Ponte ${ }^{2}$ \\ ${ }^{1}$ Department of Geography, University of Western Ontario, Canada chunsber@uwo.ca \\ ${ }^{2}$ Department of Business and Politics, Copenhagen Business School, Denmark \\ sp.dbp@cbs.dk
}

The past decade has witnessed a rapid rise in the number of policies that encourage the production and use of liquid biofuels, and a consequent rapid expansion of biofuel markets worldwide. However research has increasingly challenged claims about the 'green' credentials of biofuels and called attention to adverse environmental and social impacts associated with their production. Recent studies on indirect land use change (Fargione et al., 2008; Hertel et al., 2010; Searchinger et al., 2008) and nitrous oxide emissions from increased fertilizer use (Melillo et al., 2009), for example, have spurred a re-think of biofuels' potential to mitigate climate change. Further concerns have been raised about the impacts of expanded biofuel crop production on biodiversity (Danielsen et al., 2009; Fargione et al., 2010) and water resources (de Fraiture et al., 2008; Dominguez-Faus et al., 2009). Meanwhile, social science research has documented negative or highly unequal outcomes of biofuel production for household income, food security and land access (see for example German et al., 2011; Hodbod and Tomei, 2013; Julia and White, 2012).

Based on these and other arguments, numerous civil society groups have campaigned strenuously against biofuels. Reports by non-governmental organizations (NGOs) and social movements have stated that 'industrial agrofuels fuel hunger and poverty' by distorting food prices and disrupting livelihoods (La Via Campesina, 2009), that monoculture production of energy crops is a threat to biodiversity, food security and human rights (Biofuelwatch et al., 2007), and that demand for biofuels has driven largescale 'land grabbing' in the global South (Friends of the Earth, 2010). These groups have sought to influence public opinion as well as biofuel policies through actions including public demonstrations (Biofuelwatch, 2013), protests targeting biofuel conferences and forums (Vidal, 2008), and press statements expressing opposition to government positions on biofuels (Ernsting, 2007; The Hindu, 2007).

In this context of new knowledge and public pressure, the governance of biofuels has evolved to place greater emphasis on 'sustainability' - defined in various ways. In the European Union, United States and United Kingdom, quantity-based biofuel mandates were later modified by fuel quality standards specifying how much lower the greenhouse gas emissions of biofuels must be compared to fossil fuels (Bailis and Baka, 2011). This shift signals a narrow interpretation of environmental sustainability focused on climate change mitigation; a position consistent with assessment reports such as the Special Report on Renewable Energy Sources (IPCC, 2011) in which 'sustainable' biofuels are mainly understood to have low life-cycle greenhouse gas emissions. In some cases broader 'sustainability' measures have been introduced which aspire to address social concerns. For example, the EU Renewable Energy Directive (EU, 2009) includes reporting requirements on food availability and prices, land use rights and the status of 
labour conventions, relying on external certification systems and audits to ensure compliance. In Brazil, the National Program of Production and Use of Biodiesel (PNPB) attempts to promote social inclusion by providing incentives for smallholder farmers to participate in biodiesel production (Hall et al., 2009). India's policy of encouraging biodiesel production on 'wastelands' invokes discourses of energy security and rural poverty alleviation (Baka, this issue). New actors and arrangements have also emerged in the biofuel governance arena, such as multi-stakeholder 'roundtables' as well as public policy measures that are implemented through private certification schemes. These measures, explored and critiqued in the papers that follow, draw on very different interpretations of what sustainability looks like and how it can be achieved.

But what, if any, effects are efforts to pursue more 'sustainable' biofuels having at sites of production and processing in the global South? Analytically, the papers in this special issue examine the features of 'sustainable' biofuels in the global South through the lenses of political ecology and/or 'experimentalist' governance. Empirically, they scrutinize what happens when policies designed to improve the social and environmental performance of biofuels come into contact with complex politics, histories and social relations at the national and local levels (see also Clancy, 2013). Ultimately, they provide a strong basis for beginning to assess the impacts and challenges of efforts to govern for 'sustainable' biofuels, collectively contributing depth and breadth to discussions about the place-specific outcomes of biofuel production in the global South.

\section{Analytical perspectives}

Many of the papers in this collection adopt a political ecology approach, sometimes enriched by discourse analysis. Political ecologists emphasize understanding the political and economic systems that produce conflicts over access to resources, as well as the disproportionate impacts on impoverished people that can result from such conflicts (Bryant, 1998). Seen from this perspective, knowledge is considered to be social and contested, resources are not only 'natural' but also socially constructed, and competing claims cannot be easily dismissed (Blaikie and Brookfield, 1987; Robbins, 2012).

Crucially, a political ecology approach rests on the position that discourse and materiality are mutually influential or constituted - thus, the ability to control discourse represents a key form of power (Adger et al., 2001; Stott and Sullivan, 2000). Untangling and critically examining the relationship between discursive and material aspects of humanenvironment interactions is therefore a centrally important task. Precedents for this line of inquiry can be found in Jessop's (2004) analysis of how 'economic imaginaries' help institutions define meaning and develop strategies for particular activities; Hay and Rosamond's (2002) assertion that 'discursive constructions' can shape actors' understandings of what is possible, with tangible consequences; and Tsing's (2000) work on the role that discourse ('myth' and 'spectacle') play in attracting investment and support for new enterprises.

The papers in this special issue take up several related issues. In relation to large-scale Jatropha production, the Baka and Boamah papers ask: what political agendas are 
furthered by using particular categories to frame 'sustainable' biofuels, and who benefits and suffers from resulting outcomes? Through a case study of labour protection measures in Brazil, Labruto explores: how effectively are less powerful actors' interests represented in multi-stakeholder processes that shape the terms of an industry that employs them? In tracing divergent explanations for why cattle raising persists inside protected areas in Brazil, Newberry asks: how do narratives of responsibility and blame impede progress toward national environmental goals? These investigations contribute to more fully understanding the power relations and contested, place-specific outcomes indeed, the politics - embedded in efforts to govern for 'sustainable' biofuels.

Several contributions to this special issue also speak to the growing literature on experimentalist governance and orchestration. Common in these debates is an interest in understanding not only the role and power of market actors in shaping social and environmental governance, but also the negotiated settlements that arise from cooperation and conflict among firms, states, NGOs and other actors. This literature pays particular attention to the early stages of institutionalization, to the compromised outcomes that ensue (Auld, 2013; Bartley, 2007), and to the conditions that lead to enhanced outcomes (Guldbrandsen, 2012; Overdevest, 2010). It argues that complex governance regimes are arising in areas where there is no hegemonic power to impose rules, and where a variety of different actors operate in a number of partly overlapping fields (Alter and Meunier, 2009; Keohane and Victor, 2011; Overdevest and Zeitlin, 2012).

This literature highlights that, while this complexity can lead to individual actors seeking to achieve particularistic goals (Alter and Meunier, 2009; Schleifer, 2013), it can also provide alternative and more flexible venues to solve economic, social and environmental problems where more comprehensive governance regimes have so far failed to emerge (Abbott and Snidal, 2009; Keohane and Victor, 2011). In this context, forms of 'experimentalist governance' are arising, characterized by broad framework goals, coordinated learning and openness to periodical revision (Overdevest and Zeitlin, 2012; Sabel and Zeitlin, 2008). Experimentalist governance takes a variety of institutional forms and, according to its proponents, is better able to overcome the path dependency and institutional inertia that plague more traditional forms of governance (Overdevest and Zeitlin, 2012). As a result, many scholars are encouraging governments (and international organizations) to 'orchestrate' governance architectures (Abbott and Snidal, 2010, 2012) through 'directive' or 'facilitative' means. In the former, the state attempts to incorporate governance initiatives in its regulatory framework. In the latter, the state supports these initiatives through financing, technical assistance and endorsement.

But is orchestration in the field of biofuel governance promoting more effective governance and sustainable biofuel production? Hunsberger et al.'s and Ponte's contributions show that orchestration can create conditions for forum shopping and a race to the bottom when it comes to sustainability standards (see also Schleifer, 2013). Furthermore, Labruto's and Stattman and Mol's articles highlight how traditional regulation was actually more successful in addressing social inclusion and labour conditions in ethanol and biodiesel production in Brazil. The contributions by Larsen et al. and Boamah suggest that in many countries of the global South the capacity of the 
state to orchestrate more experimental forms of governance simply does not exist, and that strengthening the implementation of existing regulation is a prior and necessary step.

\section{Scope and themes of the collection}

This special issue opens with two framing articles. The first examines the biofuel governance landscape and identifies persistent shortcomings in addressing social and livelihood goals (Hunsberger et al.). The second highlights how biofuel sustainability certifications that are less rigorous and participatory seem to be gaining ground over consensus-based roundtables (Ponte). The collection then provides a series of in-depth and fieldwork-based case studies that engage with the question of whether and to what extent 'sustainability' measures are actually changing social and environmental practices linked to biofuel production and processing. Geographically, they draw from case studies in South America (Labruto, Stattman and Mol, Newberry), Asia (Larsen et al., Baka) and Africa (Boamah). Politically, they investigate the ways in which biofuel production and processing in the global South are affected by global certification initiatives and EU policies (Hunsberger et al., Ponte, Larsen et al.), by national regulation and standards developed in the South (Labruto, Stattman and Mol, Baka), and by strategically-deployed discourses of 'good' and 'bad' biofuels (Boamah). Thematically, they explore sustainability outcomes related to livelihoods and social inclusion (Hunsberger et al., Stattman and Mol), water resources (Larsen et al.), labour (Labruto), and land use and conservation (Newberry, Baka, Boamah).

Hunsberger et al. open the collection by reviewing selected governance mechanisms for 'sustainable' biofuels, ranging from government mandates to voluntary certifications and codes of conduct. They highlight the lack of coverage of livelihoods and equity issues in early government regulation on biofuels that included quantitative mandates in the EU and Brazil - with some improvement in later versions that included fuel quality amendments. These are aspects of biofuel production that are particularly important in the global South. Hunsberger et al. also find that voluntary certifications and codes of conduct have better coverage of these issues, but there are wide discrepancies between different initiatives, with the more comprehensive and demanding certification systems achieving smaller market coverage or success.

Ponte builds on this picture by examining in detail the genesis and development of two of the main voluntary biofuel sustainability certification systems: the Roundtable on Sustainable Biomaterial (RSB) and International Sustainability and Carbon Certification (ISCC). He shows that the ever more complex web of governance systems and procedures set in place to meet 'good practice' in standard setting and management in commodity roundtables (including RSB) is opening space for initiatives that are less democratic, quicker, and aligned with industry interests to establish substantial presence in the market for sustainability certifications (such as ISCC). The latter tend to more easily discriminate on the basis of size (against small players) and geography (against actors in the global South). 
But purportedly more inclusive and democratic processes alone are not a guarantee of successful outcomes for sustainability initiatives either. Labruto examines Brazil's 'National Commitment to Labour Conditions in Sugarcane Activity', a roundtable-style initiative that was developed in the second half of the 2000s through tripartite negotiations by labour unions, the ethanol industry and government. This process led to a voluntary programme that was intended to encourage better labour practices in sugarcane plantations through the award of certificates. This initiative overlapped with the already existing and successful government-enforced 'National Pact for the Eradication of Slave Labour', which included the maintenance of a 'dirty list' of non-compliant plantations and which imposed clear sanctions. Labruto argues that, with the new 'National Commitment' initiative, the state attempted to move from a regulatory to an arbitration function and a more mediated form of governance. This was the result of a perceived need to set up a more 'exportable' model of social sustainability than the existing 'National Pact', which was rooted on a specifically Brazilian system of bank and government sanctions. But the flattening of complex labour issues into checklists that resulted from the 'National Commitment', and the lack of sanctions for non-compliance, led to persistent violations of labour practices on plantations holding the social certificate, and to the abandonment of the initiative in mid-2013.

A second Brazilian biofuel initiative that explicitly tackled social inclusion and equity is the 'National Program of Production and Use of Biodiesel' (PNPB), which is analyzed in Stattman and Mol's paper. PNPB, a more traditional regulatory initiative, was more successful than the 'National Commitment' in the ethanol sector examined by Labruto, but also led to a number of unexpected outcomes. PNPB was designed in 2004 with the objectives of promoting biodiesel as a transport fuel and of fostering social inclusion of family farmers in the poorest regions of Brazil through their participation in the biodiesel value chain. The latter objective was addressed through the award of a mandatory 'Social Fuel Seal', allowing only biodiesel companies that buy a minimum proportion of feedstock from small farmers to sell their product in the Brazilian market via a national auction system. Although the participation of family farmers in the biodiesel value chain has remained far below expectations, a 2009 reform of PNPB led to cooperatives playing a more prominent role in the rural development of disadvantaged regions, to the benefit of a significant group of family farmers. Thus, the social biodiesel programme has resulted in more family farmers producing vegetable oils and receiving technical assistance, but has failed to promote an equal increase in the use of these oil crops towards biodiesel production.

Larsen et al. continue the exploration of whether regulation and voluntary certifications are effective tools in addressing environmental and social issues in biofuel producing countries through their case study of the impact of palm oil plantations on water resources in Central Kalimantan, Indonesia. In their paper, they provide a picture of local grievances arising from the rapid growth of palm oil plantations and report on a stakeholder appraisal of the efficacy of existing governance systems in addressing these grievances. They observe that EU regulation on sustainable biofuels does not cover impacts on water resources. While the full Roundtable for Sustainable Palm Oil (RSPO) standard contains such provisions, its RSPO-RED variation for compliance with EU 
regulation does not. Furthermore, the environmental provisions included in Indonesian law are not enforced on the ground.

The limitations of enforcing environmental regulation in the global South are further examined in Newberry's contribution, which analyzes the factors behind the continued practice of cattle grazing in mandated conservation areas by smaller producers of biofuel feedstock in Southern Goias, Brazil. He shows that even though compliance with international certification schemes by ethanol companies should leverage the application of related conservation measures, this is required only on land operated by the companies themselves - not applied to land cultivated by independent or contract farmers. But while government officials and ethanol producers attribute the persistence of these practices to the 'cultural traditionalism' and 'innate backwardness' of small farmers, Newberry shows that these farmers raise cattle in conservation areas as means of diversifying sources of income and ensuring a minimum level of income stability. In the absence of policy measures that recognize the specific needs of small farmers, attempting effective compliance with strict environmental regulation in Brazil is likely to lead to land consolidation in the hands of larger, increasingly multi-national, producers.

One of the ways in which the promotion of biofuel production in the global South has been advanced as 'sustainable' is the argument that some feedstocks can be produced effectively in lands that do not support food production and that would otherwise have little economic value. Baka's paper criticizes this argument through her examination of how India's 2003 National Mission on Biofuels affects existing land use in Tamil Nadu. The National Mission included provisions for planting Jatropha (a shrub producing nonedible oilseeds) on more 17 million ha of 'wastelands'. She finds that these lands are far from 'empty' and 'unproductive'. They support existing energy economies based on wood collection, charcoal production and electricity generation that are actually more energy-secure and economically beneficial than a Jatropha-based local economy would be. Baka argues that 'wastelands' do not actually exist and that the implementation of India's biofuel programme could actually weaken energy security, eliminate jobs and negatively affect local rural industries.

Finally, Boamah's article shows how the choice of contrasting normative concepts characterizing large-scale land deals influences the trajectory and outcomes of biofuel investments in Ghana. He shows that some of the same discursive framings of 'wastelands' highlighted by Baka in India were also used by the government of Ghana to initially promote the biofuel industry. But the discovery of new oil fields in the country later led to a withdrawal of government support for biofuel expansion and to a switch to promoting private investment in biofuels instead. In his analysis of four biofuel investments in Ghana, Boamah shows that some biofuel investments that have good potential to improve local employment and generate income have been hampered by their characterization in the media and public debate as 'land grabs'. At the same time, other investments that have been portrayed as pro-poor 'land transactions' have led to dubious outcomes. In the context of weak and unclear policy frameworks, the choice of concepts used by powerful non-state actors to frame investment decisions is becoming an alternative governance mechanism. 


\section{Political and policy implications}

The articles included in this collection raise a number of issues related to regulation and governance of 'sustainable' biofuels and their outcomes for the global South. Hunsberger et al. suggest a reversal of current policy priorities on sustainability of biofuels, where multi-criteria goals including livelihoods and equity would become ex-ante conditions in the policy hierarchy. This would mean making the social, livelihoods and equity concerns of the stricter voluntary guidelines mandatory, rather than just requiring 'reporting' of these issues, as per current EU regulation. These measures should be integrated with others that protect equitable land tenure, access to ecosystem services and economic opportunities for the rural poor. Hunsberger et al. argue that environmental policies should include incentives for biofuel production only if they met clear and specific criteria for reducing GHG emissions and strict environmental impact factors. Quantitative mandates could then move to the lowest level of the policy hierarchy, be to be pursued if and when all of the other criteria were met. This is echoed by Larsen et al., who conclude that current policy discourses centered on climate change mitigation have marginalized other natural resource concerns and livelihood issues, allowing energy security concerns in the global North to put local livelihoods in peril in the global South. In so doing, they may also be facilitating a process of 'green grabbing', a form of appropriation of resources for supposedly environmental ends (Corson and MacDonald, 2012; Fairhead et al., 2012).

Furthermore, Ponte suggests that EU regulation on sustainable biofuels should not only improve its coverage of social and environmental issues, but also establish a set of minimum standards on the quality of governance mechanisms put in place to develop, manage, monitor and evaluate the 'sustainability' of biofuels. This would lead to far more transparent and effective certification systems, more meaningful participation from feedstock producers in the South (especially smallholders) and a more geographically equitable distribution of benefits. Labruto's paper also suggests that setting up 'dialogues', 'roundtables' and multi-stakeholder fora should be seen as a tool for achieving sustainability outcomes, not an objective on its own. Experimentalist governance can actually undermine existing and effective regulation, and should be attempted only when there are clear additional benefits over more traditional regulation.

Finally, the last three articles in this collection elucidate some of the limits of enforcing environmental, land use and investment regulation in the global South while also warning against the perils of ill-designed policy. Newberry shows that different types of actors face different barriers in complying with environmental regulation. This entails that 'onesize-fits-all' instruments are not effective in facilitating compliance with conservation measures. Rather, governance mechanisms need to include features that facilitate the financial stability of weaker actors and address power relations in biofuel value chains. Baka argues that biofuel policies should not be based on the designation of 'wastelands' for biofuel production. These designations can be counter-productive, leading to weaker energy security and negatively affecting local livelihoods. Finally, Boamah argues that, in the context of weak and unclear policy frameworks, the normative choices of concepts 
used to frame land-related biofuel investment decisions become another governance mechanism. These choices, however, tend to obscure the potential benefits of some investments while protecting others against legitimate criticism. Boamah argues that a better path would be to strengthen regulatory frameworks instead. This can be done, inter alia, through compensation payments to affected residents, requirement of evidence of prospective markets for biofuels, environmental impact assessment, and the creation of periodic follow-up fora for discussion after project implementation.

Collectively, the papers in this special issue demonstrate that a substantial gap remains between the ideal of sustainable biofuels and current practices of biofuel production and processing in the global South. Traditional and experimentalist forms of governance both show considerable shortcomings - in their inclusiveness, scope, enforcement or all three - that have limited their ability to consistently improve social and environmental outcomes to date. While biofuel policies have increasingly taken up the language of social inclusion, livelihood benefits and environmental protection, the studies in this collection suggest that, based on current experience, fostering more sustainable practices in the biofuel industry remains a substantial challenge.

\section{References}

Abbott, K.W., Snidal, D., 2009. The governance triangle: Regulatory standards insitutoins and the shadow of the state, in: Mattli, W., Woods, N. (Eds.), The Politics of Global Regulation. Princeton University Press, Princeton.

Abbott, K.W., Snidal, D., 2010. International regulation without international government: Improving IO performance through orchestration. Review of International Organizations 5, 315-344.

Abbott, K.W., Snidal, D., 2012. Taking responsive regulation transnational: Strategies for international organizations. Regulation and Governance 7, 95-113.

Adger, W.N., Benjaminsen, T.A., Brown, K., Svarstad, H., 2001. Advancing a political ecology of global environmental discourses. Development and Change 32, 681715.

Alter, K.J., Meunier, S., 2009. The politics of international regime complexity. Perspectives on Politics 7, 13-24.

Auld, G., 2013. Confronting trade-offs and interactive effects in the choice of policy focus: Specialized versus comprehensive private governance. Regulation and Governance.

Bailis, R., Baka, J., 2011. Constructing Sustainable Biofuels: Governance of the Emerging Biofuel Economy. Annals of the Association of American Geographers 101 (4), 827-838.

Bartley, T., 2007. Institutional emergence in an era of globalization: The rise of transnational private regulation of labor and environmental conditions. American Journal of Sociology 113 (2), 297-351.

Biofuelwatch, Carbon Trade Watch / TNI, Corporate Europe Observatory, Econexus, Ecoropa, Crupo de Reflexion Rural, Munlochy Vigil, Friends of the Earth 
Denmark, Rettet Den Regenwald, Watch Indonesia, 2007. Agrofuels: towards a reality check in nine key areas. Transnational Institute, Amsterdam.

Biofuelwatch, 2013. Past protests. http://www.biofuelwatch.org.uk/protests/

Blaikie, P., Brookfield, H., 1987. Defining and debating the problem, in: Blaikie, P., Brookfield, H. (Eds.), Land degradation and society. Methuen, London and New York, pp. 1-26.

Bryant, R.L., 1998. Power, knowledge and political ecology in the third world: a review. Progress in Physical Geography 22 (1), 79-94.

Clancy, J. 2013. Biofuels and rural poverty. Earthscan, London.

Corson, C., MacDonald, K.I., 2012. Enclosing the global commons: the convention on biological diversity and green grabbing. Journal of Peasant Studies 39 (2), 263283.

Danielsen, F., Beukema, H., Burgess, N.D., Parish, F., Brühl, C.A., Donald, P.F., Murdiyarso, D., Phalan, B.E.N., Reijnders, L., Struebig, M., Fitzherbert, E.B., 2009. Biofuel Plantations on Forested Lands: Double Jeopardy for Biodiversity and Climate. Conservation Biology 23 (2), 348-358.

de Fraiture, C., Giordano, M., Liao, Y., 2008. Biofuels and implications for agricultural water use: blue impacts of green energy. Water Policy 10, 67-81.

Dominguez-Faus, R., Powers, S.E., Burken, J.G., Alvarez, P.J., 2009. The water footprint of biofuels: A drink or drive issue? Environmental science and Technology 43 (9), 3005-3010.

Ernsting, A., 2007. Indonesian NGO protests European biofuel plans, Indymedia UK.

EU, 2009. Directive 2009/28/EC of the European Parliament and of the Council on the promotion of the use of energy from renewable sources, L 140/16. Official Journal of the European Union, Brussels.

Fairhead, J., Leach, M., Scoones, I., 2012. Green Grabbing: a new appropriation of nature? Journal of Peasant Studies 39 (2), 237-261.

Fargione, J., Hill, J., Tilman, D., Polasky, S., Hawthorne, P., 2008. Land clearing and the biofuel carbon debt. Science 319, 1235-1238.

Fargione, J.E., Plevin, R.J., Hill, J.D., 2010. The Ecological Impact of Biofuels. Annual Review of Ecology, Evolution, and Systematics 41 (1), 351-377.

Friends of the Earth, 2010. Africa: up for grabs. Friends of the Earth Europe and Friends of the Earth Africa, Benin City, Nigeria.

German, L., Schoneveld, G.C., Pacheco, P., 2011. Local Social and Environmental Impacts of Biofuels: Global Comparative Assessment and Implications for Governance. Ecology and Society 16 (4).

Guldbrandsen, L.H., 2012. Dynamics governance interactions: evolutionary effects of state responses to non-state certification programs. Regulation and Govenance.

Hall, J., Matos, S., Severino, L., Beltrao, N., 2009. Brazilian biofuels and social exclusion: established and concentrated ethanol versus emerging and dispersed biodiesel. Journal of Cleaner Production 17, S77-S85.

Hay, I., Rosamond, B., 2002. Globalization, European integration and the discursive construction of economic imperatives. Journal of European Public Policy 9 (2), 147-167. 
Hertel, T.W., Golub, A., Jones, A.D., O'Hare, M., Plevin, R., Kammen, D.M., 2010. Global Land Use and Greenhouse Gas Emissions Impacts of U.S. Maize Ethanol: Estimating Market-Mediated Responses. Bioscience 60 (3), 223-231.

Hodbod, J., Tomei, J., 2013. Demystifying the social impacts of biofuels at local levels: where is the evidence? Geography Compass 7 (7), 478-488.

IPCC, 2011. IPCC Special Report on Renewable Energy Sources and Climate Change Mitigation. Prepared by Working Group III of the Intergovernmental Panel on Climate Change [O. Edenhofer, R. Pichs-Madruga, Y. Sokona, K. Seyboth, P. Matschoss, S. Kadner, T. Zwickel, P. Eickemeier, G. Hansen, S. Schlömer, C. Von Stechow (eds)]. Cambridge University Press, Cambridge, United Kingdom and New York, NY, USA.

Jessop, B., 2004. Critical semiotic analysis and cultural political economy. Critical Discourse Studies 1 (2), 159-174.

Julia, White, B., 2012. Gendered experiences of dispossession: oil palm expansion in a Dayak Hibun community in West Kalimantan. Journal of Peasant Studies 39 (34), 995-1016.

Keohane, R.O., Victor, D.G., 2011. The regime complex of climate change. Perspectives on Politics 9, 7-21.

La Via Campesina, 2009. Industrial agrofuels fuel hunger and poverty, The Via Campesina Notebooks, Jakarta, p. 40.

Melillo, J.M., Reilly, J.M., Kicklighter, D.W., Gurgel, A.C., Cronin, T.W., Paltsev, S., Felzer, B.S., Wang, X., Sokolov, A.P., Schlosser, C.A., 2009. Indirect emissions from biofuels: how important? Science 326, 1397-1399.

Overdevest, C., 2010. Comparing forest certification schemes: the case of ratcheting standards in the forest sector. Socio-Economic Review 8, 47-76.

Overdevest, C., Zeitlin, J., 2012. Assembling an experimentalist regime: Transnational governance interactions in the forest sector. Regulation and Governance.

Robbins, P., 2012. Political Ecology (Second Edition). Wiley-Blackwell, West Sussex.

Sabel, C.F., Zeitlin, J., 2008. Learning from difference: The new architecture of experimentalist governance in the EU. European Law Journal 14, 271-327.

Schleifer, P., 2013. Orchestrating sustainability: The case of European Union biofuel governance. Regulation and Governance.

Searchinger, T., Heimlich, R., Houghton, R.A., Dong, F., Elobeid, A., Fabiosa, J., Tokgoz, S., Hayes, D., Yu, T.-H., 2008. Use of U.S. croplands for biofuels increases greenhouse gases through emissions from land-use change. Science 319, 1238-1240.

Stott, P., Sullivan, S., 2000. Political ecology: science, myth and power. Arnold, London. The Hindu, 2007. NGOs oppose bio-fuel crops, The Hindu.

Tsing, A., 2000. Inside the economy of appearances. Public Culture 12 (1), 115-144.

Vidal, J., 2008. Protesters disrupt European biofuels summit, The Guardian. 